\title{
Arrian's Ektaxis in the Roman Empire
}

\section{Local Identity, Diversity and the Geography of the Army}

\author{
Daniel Chiritoiu \\ University of Cambridge \\ Cambridge, UK \\ daniel.chiritoiu@cantab.net \\ Received October 2019 | Accepted December 2019
}

\begin{abstract}
This paper proposes to discuss one of Arrian's so-called 'minor texts' - the Acies contra Alanos which I prefer to call Ektaxis kata Alanōn - and show how it is not only a military manual, but also allows Arrian to discuss identity, fitting into broader patterns and discourses of the Second Sophistic. In the Ektaxis Arrian, much like a sophist, creates different personas and layers of identity not just for himself but also for his troops, and takes the opportunity to present the Roman army in a diverse way, which differs from portrayals in other authors.
\end{abstract}

\section{Keywords}

military manuals - Arrian - cultural history - identity - Second Sophistic

Arrian is best known for his work on Alexander's expedition in Persia and his commentary on Alexander himself and the empire that he was creating. But Arrian was not only writing in, but equally an integral part of another empire, and it is his engagement with this which is the subject of this paper. While such engagement is surely present in the Anabasis, I address here one of Arrian's so-called 'minor works', the Ektaxis kata Alanōn. This text has generally been dismissed as a simple 'case study', a practical application of the principles found in Arrian's Taktika, which is (at least in appearance) a description of Greek and 
Roman cavalry and infantry. ${ }^{1}$ However, in what follows I will argue that Arrian also uses the setting of a face-off with the Alans as a pretext to discuss his own identity and heritage and that of the Roman empire, to make his readers both think about what it means to be Greek and Roman in the Roman empire, and also to deconstruct and challenge the very categories 'Greek' and 'Roman'.

In terms of its form, the Ektaxis is essentially a series of orders expressed in the third person imperative and infinitive meant to explain Arrian's battle array against the Alans, who attacked the borders of Cappadocia after they had plundered Albania and Media Atropatene at the behest of king Phrasmanes of Iberia (in the southern Caucasus). ${ }^{2}$ Because the text breaks off in midsentence, the question has been raised as to whether this was an individual piece or part of the Alanike - another monograph of Arrian, which Stadter assumed would have been "a geographical and ethnographical work similar to the Indike". ${ }^{3}$ Stadter argues that the Ektaxis was an independent text in close relation to the Taktika, stating that he could not imagine a work of history which would have contained this piece, because of the strange style in which it is written. ${ }^{4}$ Bosworth, however, compares it with Xenophon's Cyropaedia, where Xenophon gives the Persian king a long homily on the occasion when Cyrus marches to deliver Gadates from Assyrian attack. This homily too consists mainly of third person imperatives, with particular attention given to the names of the commanders. ${ }^{5}$ Despite suggesting that the Cyropaedia could have been Arrian's model, Bosworth, unlike Wheeler, also thinks that the Ektaxis "is hardly likely to be an extract from a formal history". This is because, just like the passage in Xenophon, it would have to be part of a harangue, but it is already longer than any direct speech in Arrian's only extant historical work, the Anabasis, and so would make for a distinct lack of balance in any historical work. ${ }^{6}$ Furthermore, Bosworth considers the very existence of an Alanike questionable, since it is based only on a reference in Photius and a "suspect attestation in John the Lydian". ${ }^{7}$

1 Stadter 1980, 46.

2 For the highly literary aspect of the text see Stadter 1980, 46; Bosworth 1993, 247; for the Alan invasion see Bosworth 1977, 219; for "a more holistic approach" to the text see Brillowski 2017.

3 Stadter 1980, 163, see also 45; Wheeler 1978.

4 Stadter 1980, 45-46.

5 X. Cyr. 5·3·34-45; Bosworth 1993, 265; Wheeler 1978.

6 Bosworth 1993, 266.

7 Bosworth 1993, 266 n. 206. 
Stadter's observation as to the position of the work in the Laurentianus manuscript (Florence, Biblioteca Medicea Laurenziana, Plut. 55.4) also makes it more likely that it is a stand-alone piece. He suggests that, since pages were removed from the manuscript for their blank parchment, and the work which followed the text in the manuscript-Onasander's treatise on generalshipbegan at the top of the verso of the same missing folio, it is likely that the recto containing the end of the Ektaxis had a blank space, which is why the folio was torn out. ${ }^{8}$ This would mean that, since a folio of the manuscript contained about forty Teubner lines, no more than twenty lines would be missing. ${ }^{9}$

If this is a stand-alone work, the reasons for its publication become even more interesting. We are presented with a whole piece where Arrian is advertising his own achievements in the Roman army and his position within the empire. The question of why Arrian might want to 'publish' the Ektaxis is fundamental to understanding the text and the bigger issues behind it. It is clearly not meant to be only a 'manual' or 'handbook', in part because the situation described is too specific to allow enough generalisation.

The text could be read as a case-study, following Stadter's line, but the idea that it demonstrates how the principles described in the Taktika can be applied cannot be dissociated from Arrian (as the man responsible for the applying) and the context in which that happens. If we then start thinking about 'publication' as a form of advertising, we might wonder what is being advertised or what questions are being raised. I believe the answer to this question is identity—both personal, local, and 'global'.

Arrian and Xenophon or Arrian as Xenophon?

One of the most striking and debated features of the treatise is the name that Arrian uses to refer to himself, Xenophon:

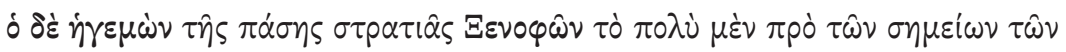
$\pi \varepsilon \zeta \measuredangle \omega \hat{\omega} \nu \dot{\eta} \gamma \varepsilon i \sigma \theta \omega .^{10}$

8 In fact, as far as I can tell, Wheeler is alone in arguing for the work being part of the Alanike.

9 Stadter 1980, 207 n. 38. The beginning of Onasander is preserved in the other manuscripts, so a cross-reference can be made; see Oldfather and Oldfather 1923, 371 and 363-365.

10 Arr. Ektax.10; all Greek passages of the Ektaxis are quoted from the Teubner edition by Roos and Wirth. 
And let the leader of the entire army, Xenophon, mostly command in front of the infantry standards. ${ }^{11}$

There has been some discussion as to whether Xenophon was an actual part of Arrian's given name. This is what Stadter argues, thinking it must be a given name simply because Arrian says it is. He believes that it does not appear in any of the inscriptions of Arrian because there he uses his official Roman name. ${ }^{12}$ But, as Bosworth notes, in the case of other individuals named Xenophon, such as Claudius' physician, C. Stertinius Xenophon, the Greek name does appear in official epigraphic contexts, which weakens Stadter's argument. ${ }^{13}$ Furthermore Stadter's parallel with Plutarch's Roman name (Maestrius), which we know only from an inscription at Delphi, does not convince, because in that inscription his Greek and Roman names do appear together, just as in the case of Stertinius. ${ }^{14}$

The question of identity is slightly more complicated if one considers the desire of certain Greeks to avoid being associated with Asia Minor and emphasize their ties to continental Greece and Athens in particular (see below). ${ }^{15}$ Arrian does indeed claim to be from Athens, although we know he was originally from Nicomedia. He became a citizen of Athens only when he retired there after his imperial career, because, as Spawforth argues, he wanted to be associated with 'true' Greece. ${ }^{16}$ A similar identity play can be seen in Polyaenus' case. He is also from Nicomedia but chose to highlight his Macedonian descent (whence his family might have come originally) to give authority to his text, as Macedonian blood increased the alleged expertise in warfare (or so he believed). ${ }^{17}$ Therefore, Bosworth must be right in stating that Arrian's reference to himself as Xenophon in the Ektaxis "is a part of the literary affectation whereby Arrian represented himself as the New Xenophon, and it is hardly likely that he would have kept up the affectation in an official document". 18

By introducing himself as Xenophon, rather than as Flavius Arrianus, the author immediately raises the idea of multiple identities with multiple traditions: suddenly the Roman commander of several legions is at the same time a Greek from Athens. The figure of Xenophon is also not chosen arbitrarily.

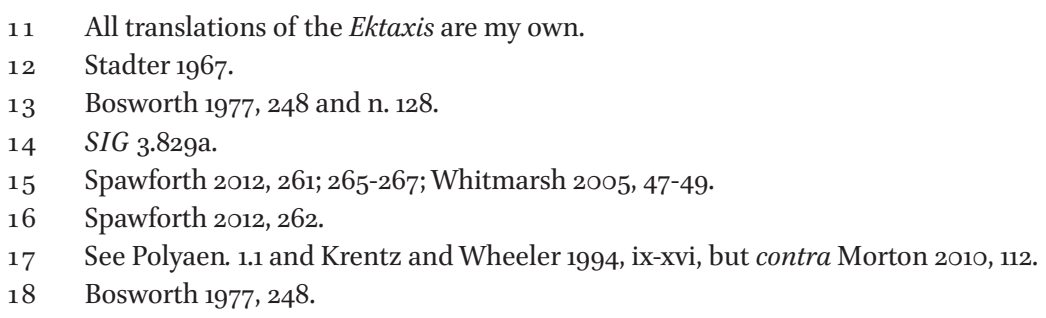


In the Hellenica (3.1.2), Xenophon refers to the writer of the Anabasis as Themistogenes of Syracuse, but scholars unanimously agree that this is a pseudonym for the writer himself. ${ }^{19}$ An admirer of Xenophon such as Arrian would appropriately have taken the opportunity to use a similar device in his own work, by referring to the protagonist of the work by a different name. The consequence in this case is to make the reader think about his different personas as author and protagonist, as citizen of Athens, but also of Nicomedia and Rome, all of which depend on the circumstances and context. Arrian, however goes beyond likening himself to Xenophon and becomes Xenophon in the context of the work, thus emphasising the fluidity and contextuality of identity. ${ }^{20}$

In all other texts by Arrian, Xenophon is identified as a distinct figure, either implicitly or explicitly. For example, in the beginning of the Periplus, Arrian

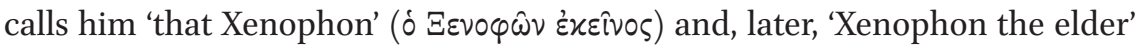

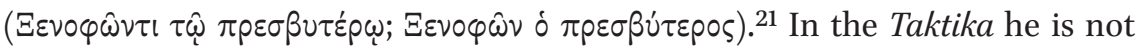
named 'the other' but it is clear that he is a different person from Arrian in a passage about other authors ('some ... others'), while in a different passage he is called Xenophon son of Gryllos, as in the preface to the Kynegetikos. ${ }^{22}$ There, Arrian also explains that he and Xenophon have the same name, but makes it very clear that they are two different people. ${ }^{23}$

In the Ektaxis, however, the 'old Xenophon' does not appear; perhaps the reader is left purposely wondering which Xenophon this is - the old or the new one? Or are they the same person? Arrian not only encourages the thought that in some sense he is Xenophon, he also adopts Xenophon's language. This is not merely a matter of using Attic vocabulary but of adopting a vocabulary of battle which was out of date and archaising. One of this has been pointed out by Bosworth and Stadter - the use of phalanx for legion-but there is more. ${ }^{24}$

First, there is the indication as to how the legionaries should raise the war cry:

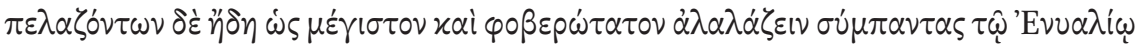
('and let all approach and raise a cry to Enyalios as loudly and terrifyingly as possible'). ${ }^{25}$ By its mention of Ares' epithet Enyalios, the passage reminds one

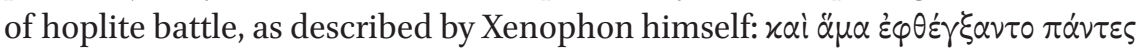

\footnotetext{
19 Millender 2012, 377 esp. n. 1.

20 For Alexander alone see Bosworth 1977; for both see Bosworth 1993, 266-267.

21 Arr. Peripl.M.Eux. 1; 12; 25 .

22 Arr. Tact. 6, 29.

23 For the clear differentiation between the two see Stadter 1967, 157, who points out that Arrian uses specific words to distinguish himself from the fourth century author.

24 Bosworth 1977, 249; for the common ways to refer to legions in Greek, see n. 135; Stadter 1980, 46 .

25 Arr. Ektax. 25.
} 


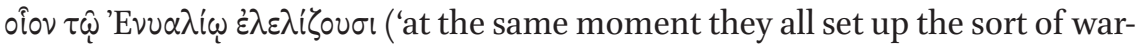
cry which they raise to Enyalios, and all alike began running') ${ }^{26}$

Second, we have the description of Arrian's entourage: oi $\delta \dot{\varepsilon} \dot{\varepsilon} \pi \hat{\imath} \lambda \varepsilon \kappa \tau 01$ i $\pi \pi \hat{\eta} \varsigma$

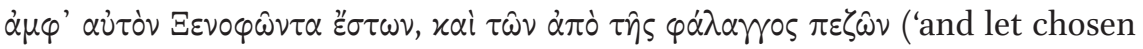
men from the cavalry surround Xenophon and from the infantry of the phalanx'). This closely resembles Xenophon's use of picked troops and his own

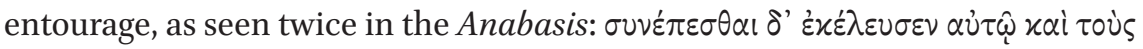

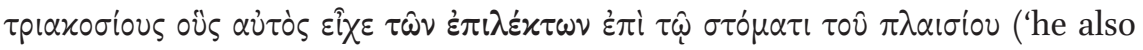
ordered the three hundred picked men under his own command at the front

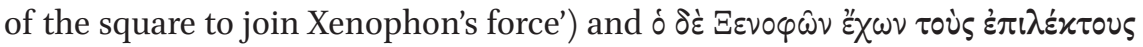

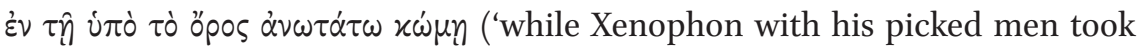
quarters in the uppermost village below the summit'). ${ }^{27}$

This is not to say that Arrian's $\dot{\varepsilon} \pi$ í $\varepsilon \varkappa \tau 0$ l were not real troops (which goes for all the troops in the text, as we shall see below) — Bosworth must surely be right in seeing the Roman equites singulares in the oi $\delta \dot{\varepsilon} \varepsilon \dot{\varepsilon} \pi \lambda \varepsilon \kappa \tau 0$ i i $\pi \pi \hat{n} \zeta$; already Polybius had used the term to refer to the Roman extraordinarii. ${ }^{28}$ However, by very subtly describing himself as operating in a way similar to Xenophon, surrounded by picked men who can be seen as both the Roman equites singulares and Xenophon's غ̇ $\pi i \lambda \varepsilon \kappa \tau 0 l$, he brings together Greek and Roman elements of his identity. Furthermore, by choosing to describe the entire army, and himself, in an archaising way, he reminds the audience of the fourth-century Xenophon and his troops without giving the impression that what he is describing is anything but a Roman provincial army: Arrian is both explaining his actions in the present and re-creating a Classical past. In the Ektaxis, then, Arrian is simultaneously Flavius Arrianus, the Roman governor leading his provincial army, and Xenophon son of Gryllos, the general from Athens, and by making the connection between his and Xenophon's army, he emphasizes the importance of continuity and tradition in one's identity.

Arrian is not unique in his approach to identity, but follows a very popular trend, namely that of sophistic declamation. As Berry and Heath point out, the composition of hypothetical or imitation speeches was a Greek invention, which "probably provided the earliest vehicle for the transmission of rhetorical theory". ${ }^{29}$ Antiphon's Tetralogies and the Helen and Palamedes of Gorgias are notable instances from the classical period. However, the real history of declamation is usually reckoned to have originated in the late fourth or early

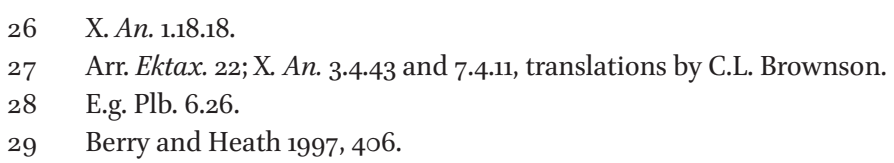


third century вС, and to have reached Rome by the first century вс. We see that many of the hypothetical cases in Cicero's De inventione and the anonymous Rhetorica ad Herennium become standard themes later on. ${ }^{30}$ Declamation became particularly popular in the second and third centuries AD, as we can see from Philostratus' Lives of the Sophists. Schmitz makes the point that historical declamations were "by far the most important class of meletai". He emphasises that "the speaker impersonated a well-known figure of classical Greek history". ${ }^{31}$ This too is illustrated by Philostratus with plenty of examples, such as Hippodromus of Thessaly (holder of the chair of rhetoric at Athens in 209213 AD and Philostratus' master) declaiming as Demades against revolting from Alexander, Apollonius of Athens speaking as Callias against the burning of the Athenian dead, and Alexander of Seleucia (born c. AD 115) impersonating Pericles and urging the Athenians to keep up the war. ${ }^{32}$

The case of Lollianus of Ephesus is particularly relevant here, as through his self-presentation he-like Arrian-is trying to achieve two goals: first, to become part of what might be called a view of Greekness that was sanctioned by Romans (a typical feature for the Hadrianic era), and second, to use this 'Roman' Greek past to augment his own prestige. Most of the information we have about Lollianus comes from Philostratus' Lives of the Sophists, but several inscriptions confirm his historicity. Philostratus tells us that he was not only appointed to the chair of rhetoric at Athens but 'also governed the Athenian

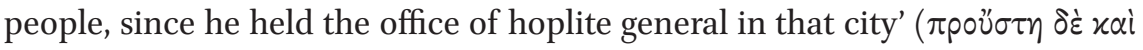

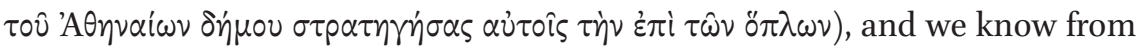
an inscription that by $142 / 143 \mathrm{AD}$ he was also a priest there. ${ }^{33}$ Philostratus continues to explain how the responsibilities of the hoplite general 'were formerly to levy troops and lead them to war, but now he has charge of the food sup-

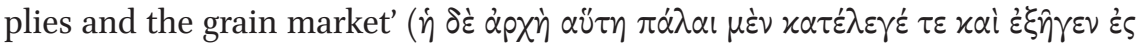

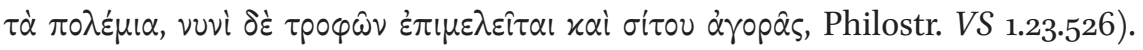
He also tells us that when a cargo of grain came from Thessaly and there was no money in the public treasury to pay for it, he bade his pupils to contribute and paid for it himself. ${ }^{34}$ This is interesting, because in one of the declamatory speeches, Lollianus, speaking as Demosthenes, denounced Leptines on

\footnotetext{
$30 \quad$ Berry and Heath 1997, 406-407.

31 Schmitz 1999, 72. For Philostratus see Jones 1974; Anderson 1986; Bowie and Elsner 2009; Kemezis 2014; König 2014.

32 Philostr. VS 2.27.620 and 2.20.6o2; nothing more is known of Apollonius of Athens.

33 Philostr. VS 1.23.526; Bowie 2006; one of the inscriptions on the statues which Philostratus tells us were dedicated to him has survived: $I G \mathrm{II}^{2} 4211$, praising his declamation and forensic speeches.

Philostr. VS 1.23.526.
} 
account of his law, because the supply of grain had failed to reach the Athenians from the Pontus. ${ }^{35}$ Lollianus, as Schmitz argues, is not merely saying what Demosthenes would have said, but, for all intents and purposes, at the moment of the speech, is Demosthenes. ${ }^{36}$ So we have someone in charge of the city grain supply who had actively provided for it and saved it on one occasion, speaking as Demosthenes, a major political figure of the fourth century BC, who also spoke for Athens and tried to ensure its grain supply. ${ }^{37}$ Furthermore, an inscription from the base of one of the two statues dedicated to Lollianus which Philostratus mentions has survived, and we see how it praises the 'sophist' for both his meletai and his actions in the law-courts. ${ }^{38}$ Lollianus is certainly not the only one of Philostratus' 'sophists' to have dabbled in the actual judicial process, but if this is taken together with his political role at Athens and his speech 'as' Demosthenes, one could infer that he actively associated himself with the fourth-century orator.

The reasons for this have to do mainly with an attitude towards Greece in general and Athens in particular, which, as Spawforth has shown, started with Augustus and continued with Hadrian. ${ }^{39}$ Spawforth argues that in building the Agrippeum at Athens, whose only recorded purpose was to stage declamatory performances, and by setting it up in the Agora, Augustus wanted to indicate both that the rhetorical tradition of Athens was being recognised and also that there was a correct, non-subversive way of using it. Spawforth points out that in the late Republic Greek politicians had used 'Asian'-style (as opposed to Attic) oratory "to inflame opinion at civic assemblies against the Roman interest". 40 This had most notably happened when the philosopher Athenion persuaded the Athenians to join Mithridates of Pontus in an alliance against the Romans.$^{41}$ The setting of the Agrippeum and encouragement of oratory in the Attic style signalled the imperial regime's "low esteem for crowd-pleasing political oratory in the prevailing 'Asian' manner" and its "preference for ...

35 Philostr. VS 1.23.527.

36 Schmitz 1999, 78: "in their declamations they actually embodied the great figures of the past; at least for the duration of their speeches, they turned into these classical authorities. ... It is important to note that in these speeches, the personality of the sophist would completely disappear behind the figure he was embodying; when he said 'I' this pronoun referred to, say, Demosthenes not to himself."

37 As Wright 1952, 100 points out, this fictitious speech is based on D. 20.30 (but also see $31^{-}$ 34), delivered by the orator in 355, where Demosthenes emphasizes that, if Leptines' law was in force then Athens would be left without grain from the Bosporus.

$38 \quad$ EpGr 877 .

39 Spawforth 2012, 6o-80.

$40 \quad$ Ibid., 78.

$41 \quad$ Ibid., 78. 
the fictional themes delivered in the decorous speech-register of Classical Athens". 42

Hadrian too gave special place to Athens when it came to Greekness, as can be seen in his attention both to the physical shape of the city and to Athens' place in relation to the Greek world in general. ${ }^{43}$ This view favoured Greekness by birth and descent to 'cultural Greekness', meaning that some cities and communities - particularly in Asia Minor and the Roman near east-, which did not have a strong connection to mainland Greece and had adopted the Greek 'way of life' and paideia, were considered less 'Greek..44 Spawforth points out that there was a rush of Greeks from Asia to mainland Greece stemming from a desire to be considered 'true Greeks'. A few examples are the Roman senators A. Claudius Charax of Pergamum and C. Claudius Titianus Demostratus of Ephesus, who were both patronomoi at Sparta, M. Iulius Apellas of Carian Mylasa, who was archon of the Eumolpidae, an anonymous citizen of Smyrna who held priestly office at Plataea, and Arrian himself who moved to Athens. ${ }^{45}$ But a willingness to be associated with the 'true Greece' can also be seen in entire cities struggling to demonstrate a 'true' Greek descent, such as Aezani in Phrygia, accepted into the Panhellenion only because they proved that they were founded by Arcadians. ${ }^{46}$

It is against this background that we should examine Lollianus' and Arrian's techniques of presentation. Since Lollianus was from Ephesus, his interest in declamation, his political activity in Athens and his intention of being associated with Demosthenes will all have served to align him to this selfsame vera Graecia, to use Spawforth's terms. But, as I suggested before, I believe Lollianus is also using the prestige of Demosthenes to augment his own prestige, as the words and actions of the two blend together in a blur of past and presentwhich at the moment of the declamation were both in the mind of audiences, as Webb argued. ${ }^{47}$ I would dare to push her argument even further and suggest that the audience judged not only the sophistic performance but also the sophist himself. Thus, by his choice of theme and comparison to Demosthenes, Lollianus is encouraging them to think of him also in the context of current Athenian civic life, suggesting that his actions rivalled those of the great orator and deserved similar credit.

\footnotetext{
42 Ibid., 79.

43 Geagan 1979, 392-393; 398; Shear 1981, 374-377; Thompson 1987, 9-15; Boatwright 200o, 148-150; Jones 1996; Spawforth and Walker 1985; Spawforth 1999.

44 Spawforth 2012; Romeo 2002.

45 Spawforth 2012, 262.

46 Spawforth 2012, 262.

47 Webb 2006, 45 .
} 
As in the case of Lollianus, the reasons for Arrian's impersonation of Xenophon are twofold. The first simply takes up Spawforth's point about him trying to adapt himself to the Roman idea of 'true' Greece. Not only, as Spawforth argues, does he move to Athens in his old age and becomes archon there, but before this, when still serving as a Roman official, he tries to construct an identity which is - from a Roman imperial point of view-incontestably Greek, using techniques similar to declamation, which is in itself a well-known practice for Romans, as well.

But second, we can see in this wish to be integrated in the empire also an issue of competition, this time between himself and the Greek past represented by Xenophon. We could also see-like with Lollianus-an attempt to use this competition both to augment his own achievements and to put them into perspective. So, can we think that, as in Lollianus' case, Arrian would have wanted to boost his reputation? If so, for what reasons? Cassius Dio's account of the war with the Alani makes it clear that it was not a particularly dangerous affair (as Arrian's preparations would have us believe), and it appears that there was no actual battle. Dio tells us that the Alani were simply frightened and

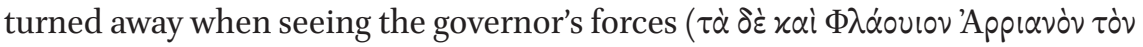

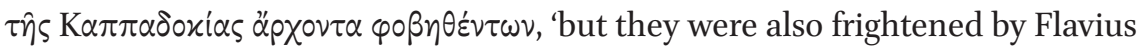
Arrianus, the governor of Cappadocia') ${ }^{48}$ Bosworth is perhaps right in believing that there was only a skirmish, and states that "it is questionable whether the Alani ever posed a serious frontier problem for the Romans. Their previous history, in so far as it is known, suggests that their depredations in general served the interests of Rome". ${ }^{49}$

No doubt repelling the Alani was essential, but given the fact that they had been on a booty expedition, it cannot have been hard; the threat to Cappadocia was minimal. In view of this, it is plausible that Arrian wanted to augment his success by blending past and present. Presenting himself in the persona of a successful general such as Xenophon and associating his prestige with Xenophon's would create a stronger impact. However, in terms of overall competition with Xenophon it could not have escaped Arrian that the fourth-century general fought as a mercenary for a Persian (and not even legitimate) ruler, Cyrus the Younger, and (even worse) with the Spartans at the battle of Coronea in 394 BC against his own city of Athens, as a punishment for which he was exiled. In comparison, Arrian not only served Athens in his old age as archon but defended the borders of the Roman Empire from (however little) danger. Therefore, the comparison between him and Xenophon does not

48 D.C. 69.15 .

49 Bosworth 1977, 220. 
automatically place him in a positive light by virtue of Xenophon's prestige. In other words, it shows how Arrian had the heritage and skills of a Xenophon but also was more successful than him, both in a Roman moral framework and in a Greek one, by serving both his patriae - the Roman Empire and Athenssuccessfully, unlike Xenophon.

But, by writing about Xenophon and himself, Arrian also opens the discussion about identity, Greeks and Romans and ideas of empire. He expands this from his own identity to that of the troops and of the people in the empire, with multiple identities functioning at once for all of them.

There is no reason to doubt that the troops mentioned in the Ektaxis are real. They have long been identified by Grotefend and more definitively by Ritterling, and if Arrian's agenda was to make a greater point about the Roman Empire, it would have made sense to use existing units, even if the description of his battle array was highly literary. ${ }^{50}$ Having said this, the very fact that scholars had to go through so much trouble to figure out the exact units to which Arrian is referring makes it quite clear that he is not primarily interested in identifying real-life troops. Unlike in the Taktika, where, as Busetto has shown, he goes to great pains to translate into Greek the exact terms used by the Roman army (sometimes having to resort to periphrases), in the Ektaxis Arrian refers to the units in various ways apart from the most straight-forward option, namely giving the name and number of the troop in question. ${ }^{51}$ Arrian uses this latter technique only twice: in paragraph one, to differenti-

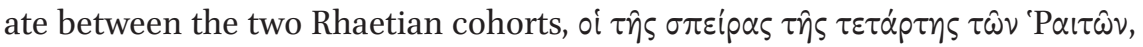
identified by Ritterling as the riders of the cohors IIII Rhaetorum equitata, sta-

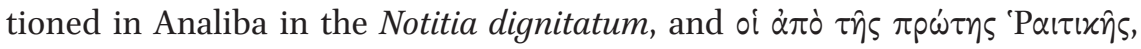
that Ritterling assumes are the horsemen of a cohors I Rhaetorum equitata, but which is not in the Notitia and cannot be identified with certainty. ${ }^{52}$ Unit numbers - without their full designation - appear concerning only two more legions: $\dot{\eta} \pi \varepsilon \zeta เ \ltimes \dot{\eta} \varphi \alpha \dot{\lambda} \lambda \alpha \gamma \xi \dot{\eta} \pi \varepsilon v \tau \varepsilon \kappa \alpha \iota \delta \varepsilon x \alpha \dot{\alpha} \tau \eta$, identified as the XV Apollinaris, and

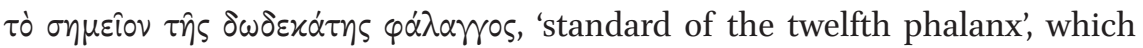

50 Grotefend 1867; Ritterling 1902; also Brillowski 2017, 203-209 for a somewhat more generic discussion of the troops used by Arrian. For the history of scholarship see Bosworth 1977, 232-233.

$5^{1} \quad$ Busetto 2013, 237.

$5^{2}$ Ritterling 1902, 369 . 
according to Ritterling is the XII fulminata. ${ }^{53}$ Arrian's preferred way of referring to troops is by their 'ethnic' names (but also names which relate to their

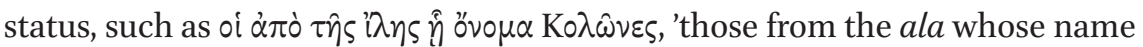
is Coloni') sometimes in conjunction with the type of unit, e.g. $\dot{\eta} \dot{i}^{\prime} \lambda \tau \tau \hat{\omega} \nu \Gamma \varepsilon \tau \hat{\omega} \nu$,

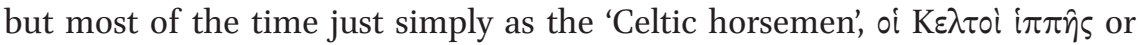

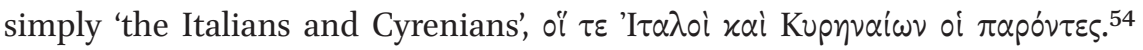
Regarding the cavalry Ritterling makes the point that when Arrian uses just the 'ethnic' names he is referring to the horsemen of a cohors, rather than an ala, which he always names. ${ }^{55}$ While this may be true, the terminology used throughout the treatise is much too inconsistent to be regarded as a well thought-out system - at least in the sense of precise identification.

The insistence on 'ethnic' epithets emphasises the diversity of peoples (and their different identities) present in the Roman army. Thus, we see the Aurianoi and Rhaetians being led by a Corinthian named Daphnes ( $\dot{\varepsilon} \pi \grave{\delta} \delta \dot{\varepsilon} \tau o u ́-$

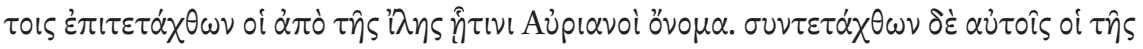

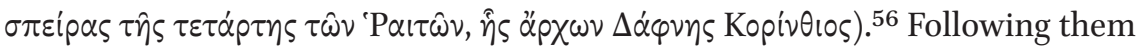

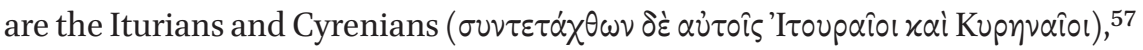
also led by someone with a Greek name-Demetrius — and after these are de-

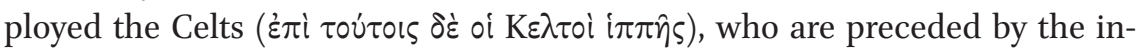
fantry, which is made up of Italians and Cyrenians under the leadership of

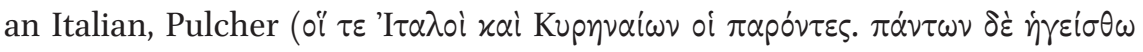

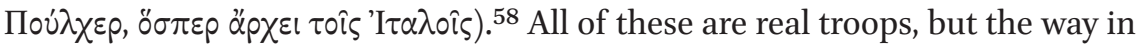
which Arrian presents them, first and foremost by using their 'ethnic' names, but also in the case of Daphnes emphasising their commander's origin, gives a very strong sense of the unique geographical diversity of the empire. A reader who understands that all these different peoples, although so diverse, had

$53 \quad$ Ritterling 1902, 361.

54 Arr. Ektax. 8; 2; 3. See Ritterling 1902, 362; 364-366 for $\dot{\eta} \mathfrak{i} \lambda \eta \tau \hat{\omega} \nu$ $\Gamma \varepsilon \tau \hat{\omega} \nu$ as the ala I Ulpia

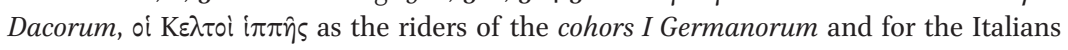
and Cyrenians as the cohors I Italica voluntariorum civium Romanorum and respectively as a vexillatio of the cohors III Augusta Cyrenaica sagittariorum equitata. See also Bosworth 1993, 265 for Arrian's insistence on national names as a parallel to Xenophon's text. The purpose is similar in both, namely to emphasize the many peoples in the service of the emperor in the former and Persian king in the latter.

55 Ritterling 1902, 362.

56 Arr. Ektax. 1; Ritterling 1902, 361 and 369 identifies them as the ala II Ulpia Auriana and, respectively, the cohors IIII Rhaetorum equitata.

57 Arr. Ektax. 2.

58 Arr. Ektax. 3; see Ritterling 1902, 367 for the more problematic cohors of Ituraioi, which is not identifiable in any inscription; and also Grotefend 1867, 24 for the difficulty in identifying the two. 
come together to fight for the empire under Arrian's command, realizes that Arrian's army is a representative of the Roman Empire as a whole, with Arrian himself acting as a surrogate for the emperor/commander.

This recognition of the diversity but also the unity within the empire is further augmented by the way Arrian uses not only the dry name and number designation —of which he is clearly aware-but emphasises that these are real people in the empire: Celts, Italians, Cyrenians, Corinthians. By presenting different ways in which one can describe troops, Arrian is also revealing the way in which the empire recognises their uniqueness and individual existence outside of the units; so the Rhaetians are part of the fourth speira but they are still Rhaetians, and a legitimate way of referring to them would be just 'the Rhaetian infantry' or the 'Rhaetian cavalry', just as Arrian refers to the $\pi \varepsilon \zeta_{0} i$...

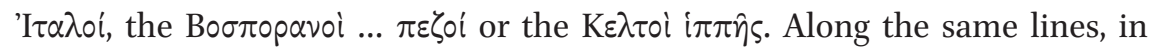

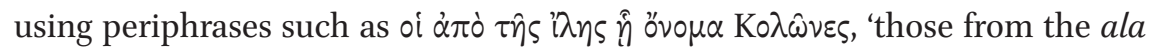
whose name is Coloni', Arrian is perhaps also emphasising that not all of the members of the ala are coloni, since new members may have been recruited from different areas due to casualties; thus the make-up of the unit may have been more diverse than its name implies, and one needs to recognise that. ${ }^{59}$

By presenting a list of all these people fighting in and for the empire, Arrian also encourages his readers to delve deeper into the dichotomy between Greek and Roman that he had established in the Taktika. It is not just Greeks and Romans who need to be acknowledged when discussing military contributions, but all these other, 'local', identities that make up the categories of 'Greek' and 'Roman' as well. ${ }^{60}$ While Corinthians and Cyrenians are all Greeks, they are different peoples, suggesting that they contribute to Arrian's army in different ways. In talking about Bosphoreans, Cyrenians, Rhizians, Apulians, Trapezuntians, and Armenians, Arrian is celebrating the local identity of his troops, of himself and of his commanders, but also the individual identity of the latter; naming them suggests that they are not merely representatives of a tribe, but Daphnes, Vasakes, Pulcher, Arbellos and Secundus. ${ }^{61}$ Commanders

59 Gilliver 2007, 193: "Auxiliary units were initially raised from Rome's provinces and were identified by their tribal or geographic origin, but gradually local recruitment where the units were stationed diluted much of their ethnic identity and in the second century AD citizens were serving in the auxiliary units as well as legions." However, I do not want to push this point too far, as the difference in name here might only be due to stylistic reasons and the desire to avoid repetition; or alternatively it might be the only way in which one could refer to these troops, as the Koloni were not a people nor were the Aurianoi in line 6 of chapter 1 , whose unit is presented in the same way.

6o Much work has been done on Greekness and local identity in recent years. See for example Whitmarsh 2010, Goldhill 2010 and Ando 2010.

61 Arr. Ektax. 1-15 gives a good idea of the range of names and peoples discussed. 
then are individuals whose skills need to be recognized irrespective of whether they are Greek, Roman, Armenian or Celtic, as we see in the case of Pulcher who, though Italian himself, is entrusted with the responsibility of leading both the Italians and the Cyrenians. ${ }^{62}$

This emphasis on unity in diversity of the Roman Empire can be paralleled with the treatment of the army in Hadrian's coinage. In the EXERCITUS series we see the provincial armies being honoured locally, with the name of the province (Britannia, Cappadocia, Dacia, Dalmatia, Germania, Hispania, Mauretania, Moesia, Noricum, Rhaetia, Syria, and Thracia) but without any iconographic particularities. So, "although honoured under local names, the armies remain Roman throughout".63

Such allowing for diversity was part of a more general Roman 'imperial programme'. As has been pointed out many times, Roman identity-down to its core in Rome's foundation myth—was inclusive. ${ }^{64}$ Roman rulers were interested only in upholding a certain set of morals and practices and did not try radically to alter the identity of those being ruled. In Woolf's words: "Greeks remained Greeks, at least in part, because Romans allowed them to. By valuing the Greek past and permitting the Greek language to operate as an official one throughout the early empire, Romans made no assault on the central defining characteristics of Hellenism". ${ }^{65}$ The same argument could be made about Arrian's presentation of Hadrian's 'reforms', which he discusses in the Taktika: the Romans organised their troops to fight in specific units (such as alae, cohorts, numeri), each commanded by a Roman (citizen), but they were perfectly happy to allow them to preserve the particularities of their fighting styles which made them very efficient and useful to the empire in the first place. ${ }^{66}$

In keeping with the theme of past and present, the geography of the empire in the Ektaxis also embraces the past, further augmenting the feeling of diversity in the Roman empire and stressing its permanence, because it spans so many peoples and so much time. This is evident in the self-same archaising which Bosworth talked about, namely in the incorporation of the tactics of the Greek phalanx in the Roman legion:

\footnotetext{
62 Arr. Ektax. 3.

63 Mattingly 1936, clxxiii.

64 Cf., e.g., Sall. Cat. 6: hi postquam in una moenia convenere, dispari genere, dissimili lingua, alii alio more viventes, incredibile memoratu est, quam facile coaluerint: ita brevi multitudo dispersa atque vaga concordia civitas facta erat.

65 Woolf 1994, 131.

66 For Hadrian's reforms see Arr. Takt. 44; for auxiliary units being commanded by Roman officers see Goldsworthy 2003, 64; for numeri Gilliver 2007, 195 .
} 


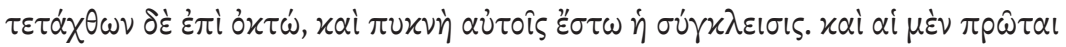

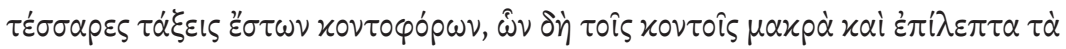

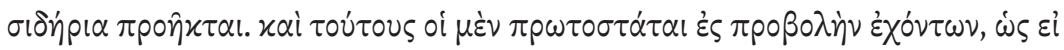

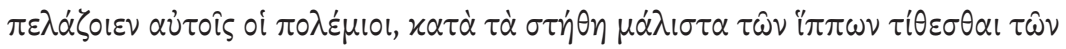

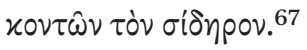

Let the ranks form eight deep and in close order; let the first four ranks be made up of those who have kontoi (long pikes), and whose kontoi have long and light iron tips attached. And these the men in their first ranks should have projecting forward, so that if the enemies approach them, the iron of the spears will be driven into the horses' chests. ${ }^{68}$

This is more than just a way in which the formations described in the Taktika can work in real life, it is recognition of the importance of the traditions of the Greeks and a demonstration of how the Empire still acknowledges and keeps them alive, just as in the case of the Celts, Getae and Rhaetians. But the Greek phalanx also becomes a tool, showing how Greek knowledge can still help order the Roman Empire more generally, and the Roman army more specifically, with Arrian both as possessor of said knowledge and the one who orders it. The phalanx is therefore placed at the centre of all the different identities as a binding factor of them all.

Would this way of looking at the empire, and particularly its armies, have been surprising to a Roman audience? It comes as no surprise that the Roman army was diverse, especially considering the makeup of auxiliaries and numeri. ${ }^{69}$ But its depiction did not always reflect that, with Plutarch and Suetonius-near contemporaries of Arrian-being the most significant

67 Arr. Ektax. 15-16.

68 Wheeler 1979 has argued that, on several occasions before Arrian's Ektaxis, the Roman army had actually incorporated the tactics of the phalanx, therefore Arrian's use is not a one-off; see also Brillowski 2017, 210-211, who follows Wheeler. While this is certainly possible (and would not-I believe-diminish the thesis of this paper, much like Arrian's use of real troops to make finer points about identity), I believe the evidence for Wheeler's case (esp. 310-314) is weak and perhaps relies too much on the tradition that the Romans had fought as a phalanx "in the Etruscan period" (304-305). In Chiritoiu 2020 I argue that the story of the adoption of the phalanx does not need to be taken at face value since it is part of a much bigger narrative of cultural interaction between Etruscans, Greeks, and Romans and fits into a picture of Roman cultural borrowing. It is perhaps also worth thinking a bit closer about what the term 'phalanx' means, as at times for Wheeler it simply seems to be a close infantry reserve force (310-311).

69 Much has been written about both. Gilliver 2007, 194-195 provides a good overview. 
counterexamples. Relevant here is the work of Ash on differentiation between different groups within an army and whether soldiers are motivated by the same emotions in Tacitus' prose. Ash provides examples of collective (or rather stereotyped) action in her analysis of the relationships between Otho, Galba and their respective soldiers. ${ }^{70}$ She notes how, in Tacitus' text, there are markedly different attitudes towards the emperor when it comes to common soldiers and their officers, which contrast with the treatment in Suetonius and Plutarch "who tend to talk more in terms of large, unstratified military groups". ${ }^{71}$ She goes on to argue that Plutarch suggests that the soldiers all support Otho for the same reason (citing Plu. Oth. 3.3), while Suetonius "assumes that all the troops are motivated by genuine concern for the emperor". ${ }^{72}$ The treatment of the soldiers in these passages of Suetonius and Plutarch might lead a reader to imagine that the army as a whole was unitary in its motivation, desires and patterns of action. Even if Tacitus takes a more nuanced approach, emphasizing differences between officers and men, and even between the men themselves, stereotypes such as 'the rabble', the 'good' and the 'bad men' are still preserved. ${ }^{73}$

Although Arrian's text is not as complex as those of these other authors, in his simple exposition he presents a more nuanced image of the troops and their background, also highlighting the roles of individuals and the mixture of ethnicities and origins. Moreover, if we assume that commanders of auxiliary cohorts and alae would normally be Roman equestrians, Arrian's choice to emphasise their ethnic origins also makes a point both about the inclusiveness of Roman citizenship and the breadth of meaning that the term carries. ${ }^{74}$ For example, the aforementioned Daphnes is a Corinthian, a Greek but presumably also a Roman citizen so that, like for Arrian himself, his motivations, interests and actions are determined by all those identities. After reading Arrian one might exercise caution when thinking that 'Roman citizen' means the same thing for everyone. Moreover, Daphnes is in charge of a cohort of Rhaetians: the way in which his troops behave is an aggregate of all the complex intersections of ethnic, societal and cultural factors that are implied in such a pairing.

In conclusion, Arrian uses the Ektaxis to explore issues of identity-both his own and that of his troops, emphasizing difficulties of definition and

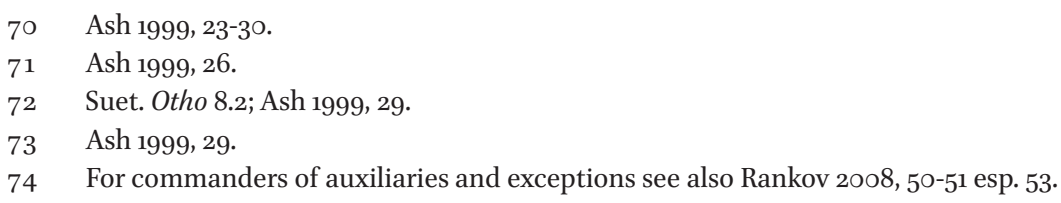


categorization. Both in his own case and in that of the troops he challenges assumptions about what it means to be Roman and about the blanket application of such a term. He emphasizes that Romanitas has become an amalgam of cultures and identities. Greek culture and history are shown to have a special place in this Romanitas, one that can still be used to shape and organize the empire, but Arrian encourages cherishing the empire's diversity and individuality and shows how a successful leader-such as himself-should take all those things into account.

\section{Acknowledgment}

I owe a great deal of gratitude to Professor Robin Osborne for his comments and continued support of this paper and to Dr. Rebecca Flemming for her suggestions, encouragement and lively discussions on the topic of Arrian' identity. My warmest thanks go to Franco Basso for his observations on Xenophon's own identity. I would also like to thank the reviewers for their criticism and very valuable suggestions, which greatly improved the paper.

\section{Bibliography}

Anderson, G. (1986). Philostratus. Biography and belles lettres in the Third Century A.D. London.

Ando, C. (2010). Imperial Identities. In: T. Whitmarsh, ed., Local Knowledge and Microidentities in the Imperial Greek World, Cambridge, pp. 17-45.

Ash, R. (1999). Ordering Anarchy. Armies and Leaders in Tacitus' Histories. London.

Berry, D.H., and Heath, M. (1997). Oratory and Declamation. In: S. Porter, ed., Handbook of Classical Rhetoric in the Hellenistic Period, 330 B.C.-A.D. 400, Leiden, pp. 393-420.

Boatwright, M.T. (2000). Hadrian and the Cities of the Roman Empire. Princeton/ Oxford.

Bosworth, A.B. (1977). Arrian and the Alani. HSCP 81, pp. 217-255.

Bosworth, A.B. (1993). Arrian and Rome. The Minor Works. ANRW II.34, pp. 226-275.

Bowie, E.L. (2006). Lollianus. In: H. Cancik and H. Schneider, eds., Brill's New Pauly, http://dx.doi.org/10.1163/1574-9347_bnp_e709370.

Bowie, E., and Elsner, J., eds. (2009). Philostratus. Cambridge.

Brillowski, W. (2017). The Principles of ars tactica. Roman Military Theory and Practice in Arrian's Acies contra Alanos. In: P. Rance and N.V. Sekunda, eds., Greek Taktika. Ancient Military Writings and its Heritage, Gdansk, pp. 195-216. 
Busetto, A. (2013). Linguistic Adaptation as Cultural Adjustment. Treatment of Celtic, Iberian, and Latin Terminology in Arrian's Tactica. Journal of Ancient History 1, pp. 230-241.

Chiritoiu, D.A. (2020, forthcoming). The 'Myth' of the Phalanx. Battle Formations and Cultural Interactions. CCJ 66 [avaliable online https://doi.org/10.1017/S175027052 ooooo32].

DeVoto, J.G. (1993). Technē taktike. Ektaxis kata Alanōn = Tactical Handbook, and The Expedition against the Alans. Chicago.

Geagan, D.J. (1979). Roman Athens. Some Aspects of Life and Culture I. 86 B.C.-A.D. 267. ANRW 7 , pp. 371-437.

Gilliver, K. (2007). The Augustan Reform and the Structure of the Roman Army. In: P. Erdkamp, ed., A Companion to the Roman Army, Malden, MA/Oxford, pp. 183-20o.

Goldhill, S. (2010). What is Local Identity? The Politics of Cultural Mapping. In: T. Whitmarsh, ed., Local Knowledge and Microidentities in the Imperial Greek World, Cambridge, pp. 46-68.

Goldsworthy, A.K. (2003). The Complete Roman Army. London.

Grotefend, C.L. (1867). Die Truppencorps in Arrians Marschordnung gegen die Alanen. Philologus 26, pp. 18-28.

Jones, C.P. (1974). The Reliability of Philostratus. In: G.W. Bowersock, ed., Approaches to the Second Sophistic, University Park, PA, pp. 11-16.

Jones, C.P. (1996). The Panhellenion. Chiron 266, pp. 29-56.

Kemezis, A.M. (2014). Greek Narratives of the Roman Empire under the Severans. Cambridge/New York.

König, J. (2014). Images of Elite Community in Philostratus. Re-reading the Preface to the Lives of the Sophists. In: J.M. Madsen and R. Rees, eds., Roman Rule in Greek and Latin Writing, Leiden, pp. 246-270.

Krentz, P., and Wheeler, E. (1994). Polyaenus, Stratagems of War. Chicago.

Mattingly, H. (1936). Coins of the Roman Empire in the British Museum, Vol. 3: Nerva to Hadrian. London.

Millender, E. (2012). Spartan 'Friendship' and Xenophon's Crafting of the Anabasis. In: F. Hobden and C. Tuplin, eds., Xenophon. Ethical Principles and Historical Enquiry, Leiden/Boston, pp. 377-425.

Morton, J. (2010). Polyaenus in Context. The Strategika and Greek Identity in the Second Sophistic Age. In: K. Brodersen, ed., Polyainos. Neue Studien, Berlin, pp. 108-132.

Oldfather, W.A., and Oldfather, C.H. (1923). Aeneas Tacticus, Asclepiodotus, Onasander. London.

Rankov, B. (2008). Military Forces. In: P. Sabin, H. van Wees, and M. Whitby, eds., The Cambridge History of Greek and Roman Warfare, Vol. 2, Cambridge, pp. 30-75.

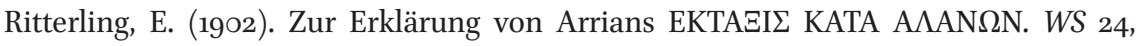
pp. 359-372. 
Romeo, I. (2002). The Panhellenion and Ethnic Identity in Hadrianic Greece. CPh 97, pp. 21-37.

Shear, T.L. (1981). Athens from City-State to Provincial Town. Hesperia 5o, pp. 356-377. Schmitz, T.A. (1999). Performing History in the Second Sophistic. In: M. Zimmerman, ed., Geschichtsschreibung und politischer Wandel im 3. Jh. n. Chr., Stuttgart, pp. 71-93. Spawforth, A.J.S. (1999). The Panhellenion Again. Chiron 29, pp. 339-352.

Spawforth, A.J.S. (2012). Greece and the Augustan Cultural Revolution. Cambridge.

Spawforth, A.J.S., and Walker, S. (1985). The World of the Panhellenion. I. Athens and Eleusis. JRS 75, pp. 78-104.

Stadter, P.A. (1967). Flavius Arrianus. The New Xenophon. GRBS 8, pp. 155-161.

Stadter, P.A. (1980). Arrian of Nicomedia. Chapel Hill.

Thompson, H.A. (1987). The Impact of Roman Architects and Architecture on Athens 170 B.C.-A.D. 170. In: S. Macready and F. Thompson, eds., Roman Architecture in the Greek World, London, pp. 1-17.

Webb, R. (2006). Fiction, Mimesis and the Performance of the Past in the Second Sophistic. In: D. Konstan and S. Saïd, eds., Greeks on Greekness. Viewing the Greek Past under the Roman Empire, Cambridge, pp. 27-46.

Wheeler, E. (1978). The Occasion of Arrian's Taktika. GRBS 19, pp. 351-365.

Wheeler, E. (1979). The Legion as Phalanx. Chiron 9, pp. 303-318.

Whitmarsh, T. (2005). The Second Sophistic. Oxford.

Whitmarsh, T. (2010). Thinking Local. In: T. Whitmarsh, ed., Local Knowledge and Microidentities in the Imperial Greek World, Cambridge, pp. 1-16.

Woolf, G. (1994). Becoming Roman, Staying Greek. Culture, Identity and the Civilizing Process in the Roman East. PCPhS 40, pp. 116-143.

Wright, C.W. (1952). Lives of the Sophists. Philostratus and Eunapius. London/ Cambridge, MA. 